\title{
Denitrifying granules in a marine Upflow Anoxic Sludge Bed (UASB) reactor
}

\author{
Letelier-Gordo, Carlos Octavio; Herreros, Miguel Martin
}

Published in:

Aquacultural Engineering

Link to article, DOI:

10.1016/j.aquaeng.2018.12.002

Publication date:

2019

Document Version

Peer reviewed version

Link back to DTU Orbit

Citation (APA):

Letelier-Gordo, C. O., \& Herreros, M. M. (2019). Denitrifying granules in a marine Upflow Anoxic Sludge Bed (UASB) reactor. Aquacultural Engineering, 84, 42-49. https://doi.org/10.1016/j.aquaeng.2018.12.002

\section{General rights}

Copyright and moral rights for the publications made accessible in the public portal are retained by the authors and/or other copyright owners and it is a condition of accessing publications that users recognise and abide by the legal requirements associated with these rights.

- Users may download and print one copy of any publication from the public portal for the purpose of private study or research.

- You may not further distribute the material or use it for any profit-making activity or commercial gain

- You may freely distribute the URL identifying the publication in the public portal

If you believe that this document breaches copyright please contact us providing details, and we will remove access to the work immediately and investigate your claim. 


\section{Accepted Manuscript}

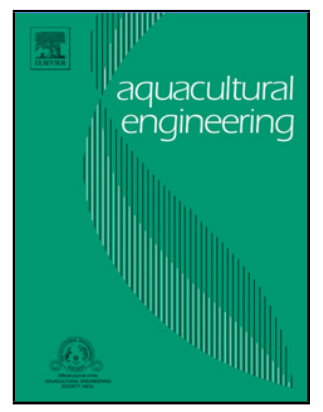

Title: Denitrifying granules in a marine Upflow Anoxic Sludge Bed (UASB) reactor

Authors: Carlos O. Letelier-Gordo, Miguel Martin Herreros

PII: $\quad$ S0144-8609(18)30174-2

DOI: $\quad$ https://doi.org/10.1016/j.aquaeng.2018.12.002

Reference: $\quad$ AQUE 1971

To appear in: $\quad$ Aquacultural Engineering

Received date: 6 December 2018

Accepted date: $\quad 10$ December 2018

Please cite this article as: Letelier-Gordo CO, Herreros MM, Denitrifying granules in a marine Upflow Anoxic Sludge Bed (UASB) reactor, Aquacultural Engineering (2018), https://doi.org/10.1016/j.aquaeng.2018.12.002

This is a PDF file of an unedited manuscript that has been accepted for publication. As a service to our customers we are providing this early version of the manuscript. The manuscript will undergo copyediting, typesetting, and review of the resulting proof before it is published in its final form. Please note that during the production process errors may be discovered which could affect the content, and all legal disclaimers that apply to the journal pertain. 


\title{
Denitrifying granules in a marine Upflow Anoxic Sludge Bed (UASB) reactor
}

Carlos O. Letelier-Gordo ${ }^{a, \star}$, Miguel Martin Herreros ${ }^{a}$

a Technical University of Denmark, DTU Aqua, Section for Aquaculture, North Sea Research

Centre, DK-9850 Hirtshals, Denmark. *Corr. author Email address: colg@aqua.dtu.dk

\section{Highlights}

- Granular formation was achieved in 27 days at marine (35 ppt) conditions.

- Highest specific denitrification rate was achieved at up-flow velocity of $0.97 \mathrm{~m} / \mathrm{h}$.

- The UASB reactor removed up to $14.9 \mathrm{~kg} \mathrm{NO}_{3}{ }^{-} \mathrm{N} / \mathrm{m}^{3}$ reactor $/ \mathrm{d}$.

\begin{abstract}
Marine land-based Recirculating Aquaculture Systems (RAS) are generally perceived as environmentally friendly aquatic production systems. To promote their sustainability even further and reduce the discharge of nutrients, there is a need for cost-effective end-of-pipe treatment technologies for removing nutrients. This includes nitrate-nitrogen $\left(\mathrm{NO}_{3}{ }^{-} \mathrm{N}\right)$ for which well-proven technologies for freshwater systems exists, while similar technologies for saltwater systems are less advanced. Granular technology has been developed since the 1970s in wastewater treatment under the upflow anaerobic sludge bed (UASB) concept. This concept is based on the enrichment of different bacterial aggregations into a compact granule, optimizing synergistic and syntrophic bacterial processes by reducing the diffusion distance of substrates between the different bacterial consortia forming the granule. The following study examined the: 1) granular formation; and 2) nitrate removal capacity of a marine Upflow Anoxic Sludge Bed (UASB) reactor operating at different up-flow velocities $(0.40-2.11 \mathrm{~m} / \mathrm{h})$. The results showed that marine denitrifying granules developed within 27 days using preconditioned rainbow trout (Oncorhynchus mykiss) organic matter waste, and that the highest specific denitrification rate $\left(321.9 \pm 13.1 \mathrm{mg} \mathrm{NO}^{-}{ }^{-} \mathrm{N} / \mathrm{g}\right.$ Total Volatile Suspended Solids (TVSS)/d) was found at an upflow velocity of $0.97 \mathrm{~m} / \mathrm{h}$. The marine
\end{abstract}


UASB denitrifying granule reactor had a total capacity of removing $14.9 \mathrm{~kg} \mathrm{NO}_{3}-\mathrm{N} / \mathrm{m}^{3}$ reactor volume per day at a hydraulic retention time of $1.9 \mathrm{~h}$, making it a strong candidate for end-of-pipe denitrification of marine RAS effluent as well as for in-line treatment in marine systems.

Keywords: Denitrification, Granular sludge, Upflow anoxic sludge bed.

\section{Introduction}

With increasing construction of marine land based facilities, adequate solutions are required to reduce the nitrate levels discharged in order to comply with environmental legislation, increase water recirculation intensity within systems and most of all, to treat saline effluents. Recirculating Aquaculture Systems (RAS) employ nitrifying bacteria in order to increase water recirculation intensity. Nitrifying bacteria live attached to inert carriers inside "biofilters" with the purpose of oxidizing ammonium $\left(\mathrm{NH}_{4}^{+}\right)$resulting in the production of nitrate $\left(\mathrm{NO}_{3}{ }^{-}\right)$, which thus accumulates in RAS. Nitrate constitutes more than $80 \%$ of the total nitrogen (TN) in RAS effluents (Timmons et al., 2009).

If a reduction in $\mathrm{TN}$ discharge is required, biological denitrification (i.e., removal of nitrate from the water phase) is one of the most cost efficient end-of-pipe treatment method to apply (Tchobanoglous et al., 2003). Bacterial mediated denitrification using media-laden reactors has been the most common way to remove nitrate from freshwater RAS (Arbiv and van Rijn, 1995; Suzuki et al., 2003; Suhr et al., 2014; Tsukuda et al., 2015) and saline RAS water (Balderston and Sieburth, 1976; Honda et al., 1993; Grguric et al., 2000; Tal et al., 2009; Gutierrez-Wing et al., 2012). Media-based reactors have proven reasonably successful, although associated media costs, pressure drop, and need for backwash of the media to avoid channeling or clogging (Sauthier et al., 1998) are major disadvantages of this technology.

The granule concept (Lettinga et al., 1980) may become an interesting alternative to media-based denitrification systems in aquaculture. Granules consist of semi-spherical bacterial aggregations with high settling capacities. During granule formation, bacteria initially form flocs as in activated 
sludge systems and under well-defined selection pressure (e.g. upflow velocity), the lighter nonflocculating biomass is washed out while the heavier well-settling aggregates remain in the reactor (Lettinga, 1995).

A large variety of organisms can perform granulation, however, the speed of the process and the type of granule formed will depend on a series of factors. The most relevant factors are: 1) the characteristics of the substratum for the bacteria to adhere (e.g., porosity, density of the nucleus and specific surface area) (Yoda et al., 1989; Yu et al., 1999; Lee et al., 2004); 2) environmental conditions such as pH, temperature and water ionic strength (Winkler et al., 2012); and 3) the properties of the involved organisms such as bacterial morphology and production of extra cellular polymers (O'Flaherty et al., 1997). Additionally, granular sludge has a series of advantages over flocculent sludge (i.e., commonly utilized in activated sludge systems). Important advantages are: 1) a higher resistance to hydraulic stress (Di Laconi et al., 2005); 2) heterogeneous stratified bacterial populations with high syntrophic and symbiotic interactions allowing simultaneous processes to carry on (i.e. nitrification and denitrification) (Fig. 1) (Schmidt and Ahring, 1996; Wagner et al., 2015); 3) additional protection of bacteria from predators (e.g. protozoa); and 4) a minimized diffusion distance between different bacterial layers, allowing a more efficient energy utilization by the bacteria (Klapwijk et al., 1981).

Figure 1: Schematic representation of a granule, modified from Giesen et al. (2015).

Upflow Anaerobic/Anoxic Sludge Bed (UASB) is the most common reactor type utilizing granular sludge. The reactor does not require an inert carrier (plastic), can achieve very efficient mixing, does not present clogging problems, and it is widely used in high-rate anaerobic wastewater treatment systems (Henze et al., 2008).

In an UASB reactor, water enters at the bottom creating an upward plug-flow that maintains the granules in suspension. The key indicators of granular sludge formation and correct system performance are: 1 ) the ratio between TVSS (Total Volatile Suspended Solids) and TSS (Total 
Suspended Solids); 2) the Sludge Volume Index (SVI); and 3) the upflow velocity $\left(\mathrm{V}_{\mathrm{u}}\right)$. The ratio between TVSS/TSS characterizes the degree of organic matter in relation to inert material contained in the granule. The SVI is an indicator of the settling capacity of the granular sludge (APHA, 1995). The upflow velocity is the velocity at which the water rises from the bottom to the upper part of the UASB.

Studies using UASB reactors for denitrification in wastewater treatment have shown different removal rates. Buvanesh et al. (2013) reported removal rates of $740 \mathrm{~g} \mathrm{NO}_{3}{ }^{-}-\mathrm{N}^{-} \mathrm{m}^{3}$ reactor volume at a hydraulic retention time of $6 \mathrm{~h}$, using acetate and ethanol as carbon sources. Galbova et al. (2010), feeding an Up-flow Sludge Blanket (USB) with ethanol, was able to remove 2.7 - $3.7 \mathrm{~kg}$ $\mathrm{NO}_{3}-\mathrm{N} / \mathrm{m}^{3}$ reactor volume using granular sludge as inoculum. Klapwijk et al. (1981) reported a nitrate removal capacity of $12 \mathrm{~kg} \mathrm{NO}_{3}-\mathrm{N} / \mathrm{m}^{3}$ reactor volume when using an UASB fed with an alcoholic waste solution and operated at an upflow velocity of $2 \mathrm{~m} / \mathrm{h}$. In aquaculture, studies based on this technology have been applied solely to evaluate organic matter removal (Mirzoyan et al., 2010). To our knowledge, no information exists on the removal capacity and associated operational parameters of an UASB reactor used for nitrate removal from marine aquaculture effluent. The following study evaluated the granular formation and nitrate removal capacity of a marine (35 ppt salinity) UASB operated under different upflow velocities.

\section{Materials and methods}

\subsection{Experimental setup}

The experimental work was divided into three main phases (Table 1). In Phase I or inoculum preparation phase, fish waste was conditioned during 14 days in a separate step-batch setup to achieve flocculent sludge. In Phase II or granulation phase (60 days) the conditioned flocculent sludge was transferred to the UASB reactors. The UASB reactors were operated under a stepbatch configuration and granulation morphology and maximal denitrification rates were evaluated. Finally, in Phase III or the performance phase (49 days), the nitrate removal capacity of the 
granules was assessed against different operational upflow velocities applied in the UASB reactors operated in a flow-through configuration (Table 1).

Table 1: Overview of the experimental time schedule applied operational carbon and nitrate concentrations in the UASB reactors $(n=3)$

\subsection{Reactors}

The experimental work was carried out in three replicated cylindrical acrylic UASB reactors. Each reactor had an operational volume of $10 \mathrm{~L}$, a total height of $1.8 \mathrm{~m}$, and a cross sectional area of $0.06 \mathrm{~m}^{2}$ (Fig. 2). Each reactor had a rotational metal grid working as a mixing device inside. The metal grid reached the full height of the reactor and was operated at $25 \mathrm{rpm}$. Each reactor had seven sampling ports distributed along the length of the reactor. Substrates (carbon and nitrate) for the bacteria were injected at the bottom of the reactor (below the $1^{\text {st }}$ sampling port) and the effluent was discharged at the upper port ( $7^{\text {th }}$ port) (Fig. 2). The frequencies at which substrate was delivered to the UASB reactors depended on the experimental Phase as further described below.

Figure 2: Schematic representation of the UASB set up.

\subsection{Experimental Phases}

\subsubsection{Phase I: Inoculum and stock media preparation}

Denitrifying flocculent sludge was prepared using organic waste obtained from the settler cones of an experimental rainbow trout (Oncorhynchus mykiss) marine RAS (salinity of $25 \mathrm{ppt}$ ). The organic waste was pre-conditioned in 10 L Pyrex® media bottles (Sigma-Aldrich, Denmark) fed with sodium acetate $\left(\mathrm{C}_{2} \mathrm{H}_{3} \mathrm{NaO}_{2},>99 \%\right.$, GPR RECTAPUR@, VWR, USA) and sodium nitrate $\left(\mathrm{NaNO}_{3}\right.$, $>99 \%$, Acros Organics, USA). To condition the fish organic waste, the $10 \mathrm{~L}$ bottles were filled with $5 \mathrm{~L}$ of rainbow trout organic waste at a concentration of $10 \mathrm{~g} / \mathrm{L}$ COD (Chemical Oxygen Demand) and the remaining volume was filled with marine water (salinity of $35 \mathrm{ppt}$ ). The $10 \mathrm{~L}$ bottles were 
operated under a step-fed batch configuration (Tchobanoglous et al., 2003) with one cycle per day. The cycle was divided into a mixing period (250 rpm, $23.5 \mathrm{~h}$ ) using a magnetic stirrer (IKKA C-Mag MS 7, Germany) and a subsequent settling period where the magnetic stirrers were turned off, letting bacteria settle for $30 \mathrm{~min}$. After settling, $40 \%$ of the upper bottle volume (supernatant) was discharged to finish a cycle. To start a new cycle, the bottles were re-filled ( $40 \%$ of bottle volume) with sodium acetate to a final concentration of $1 \mathrm{~g} / \mathrm{L} \mathrm{COD}$, sodium nitrate to a final concentration of $250 \mathrm{mg} / \mathrm{L} \mathrm{NO}_{3}-\mathrm{N}$, and full mixing was initiated (250 rpm). This condition process (inoculum phase) lasted for two weeks during which a clear separation of bacteria with good settling properties was achieved. The bacterial mass was collected and used to fill up the UASB reactors, initializing the granulation phase (Phase II).

\subsubsection{Phase II: Granulation phase}

Each UASB reactor was operated under a step-fed batch configuration during the granulation phase (Tchobanoglous et al., 2003), recirculating water from port 7 (effluent) to port 1, using a peristaltic pump (Longer Pump YZ1515x, Longer Precision Pump Co., Ltd., China) with three separate head pumps, one for each reactor. Water inside each reactor recirculated at a flow of 55 $\mathrm{L} / \mathrm{d}$, corresponding to an upflow velocity $\left(\mathrm{V}_{\mathrm{u}}\right)$ of $0.40 \mathrm{~m} / \mathrm{h}$. Once per day, the pump was turned off and followed by a 30 min settling period. At the end of the settling period, $1 \mathrm{~L}$ sample was taken from the upper reactor port and replaced with marine water (35 ppt). Daily, the UASB reactors were fed with a solution (feeding solution) prepared by mixing $150 \mathrm{~mL}$ of Milli-Q® water with 19.48 g sodium acetate $\left(\mathrm{C}_{2} \mathrm{H}_{3} \mathrm{NaO}_{2},>99 \%\right.$, GPR RECTAPUR@, VWR, USA $)$ and $15.17 \mathrm{~g}$ sodium nitrate $\left(\mathrm{NaNO}_{3}>99 \%\right.$, Acros Organics, USA) to obtain a final concentration inside the reactors of $1500 \mathrm{mg}$ $\mathrm{COD} / \mathrm{L}$ and $250 \mathrm{mg} \mathrm{NO}_{3}{ }^{-} \mathrm{N} / \mathrm{L}$. These proportions of acetate and nitrate were used to achieve a carbon-nitrogen ratio $(\mathrm{C}: \mathrm{N})$ of 6 , ensuring that the denitrification process would not become carbon limited (Henze et al., 2002). Every second day, the feeding solution was supplemented with a medium solution to improve granulation. The medium solution was modified from the one described by Val del Rio et al. (2015) where the compounds already found in sea water were 
excluded. The modified medium solution (amounts normalized to $\mathrm{mg} \mathrm{N}$ ) consisted of: phosphate (0.16 mg KH $\left.2 \mathrm{PO}_{4}\right)$, ammonium (0.50 mg $\left.\left(\mathrm{NH}_{4}\right)_{2} \mathrm{SO}_{4}, 0.42 \mathrm{mg} \mathrm{NH} \mathrm{N}_{4} \mathrm{Cl}\right)$, and micronutrients $\left(14.11 \times 10^{-2} \mathrm{mg} \mathrm{MgSO}_{4}, 11.41 \times 10^{-6} \mathrm{mg} \mathrm{CuCl}_{2}, 15.78 \times 10^{-5} \mathrm{mg} \mathrm{CoCl}_{2}, 3.00 \times 10^{-5} \mathrm{mg} \mathrm{MnCl}_{2}\right.$, and $\left.3.68 \times 10^{-5} \mathrm{mg} \mathrm{Na}_{2} \mathrm{MoO}_{4}\right)$.

To characterize the granule formation, samples for TSS, TVSS, and SVI were collected at port 7 once per week. Temperature and $\mathrm{pH}$ were measured daily using a portable multi-meter (Hach HQ40d, Hach Lange, USA). The morphological development of the granules was studied twice per week under a microscope. A stereomicroscope (Leica MZ6, Leica Microsystems, Germany) and an inverted microscope (Leica DMLB, Leica Microsystems, Germany) mounted with a Progres Gryphax® Subra (Jenoptik, Germany) microscope camera were used to capture granule images processed with the Progress Gryphax® software. Diameters of the granules were measured using the open source freeware ImageJ.

\subsubsection{Phase III: Performance phase (upflow velocity evaluation)}

During the performance phase, seven different upflow velocities $\left(V_{u}\right)$ in the UASB reactor were tested over a total period of 7 weeks (one upflow velocity per week). Velocities tested ranged from $0.40 \mathrm{~m} / \mathrm{h}$ to $2.11 \mathrm{~m} / \mathrm{h}$ changed in intervals of $0.29 \mathrm{~m} / \mathrm{h}$ (Table 2). For this purpose, the operation of the UASB reactors was changed from a step-fed batch configuration to a flow-through configuration. Peristaltic pumps (Longer Pump YZ1515x and Longer Pump BT100-2J) connected to separate ports at the bottom of the reactor were used to continuously provide saline water (35 ppt) and feeding solution (acetate and nitrate) to the reactor. The composition of the feeding solution was modified for each $\mathrm{V}_{\mathrm{u}}$ in order to deliver a constant concentration of $100 \mathrm{mg} / \mathrm{L} \mathrm{NO}_{3}{ }^{-} \mathrm{N}$ and aiming at a C:N ratio of 6 in all tests (Table 2). Thus, the nutrient load applied to the reactors ranged from 5 to $30 \mathrm{~g} \mathrm{NO}_{3}-\mathrm{N} / \mathrm{d}$ and from 35 to $190 \mathrm{~g}$ acetate $/ \mathrm{d}$.

Table 2: Up-flow velocities $\left(\mathrm{V}_{\mathrm{u}}\right)$, hydraulic retention time (HRT), flow and daily mass of feeding solution delivered to each of the triplicate UASB reactors in the performance phase (Phase III). 
The effluent from each reactor discharged into a $5 \mathrm{~L}$ bucket from where $24 \mathrm{~h}$ pooled samples were obtained using an automatic portable sampler (Glacier ISCO 4700, Teledyne, USA) sampling 200 $\mathrm{mL}$ each hour. Collected samples were stored at $4^{\circ} \mathrm{C}$ until laboratory analysis. Temperature, dissolved oxygen (DO), and pH were measured daily at the effluent port of the reactors, using a portable multi-meter instrument (Hach HQ40d, Hach Lange, USA).

Nutrient removal was determined 3 times for each operational $V_{u}$ and the corresponding denitrification rate was calculated (Eq. 2). Morphology (as described in section 2.3.2) and quality (TSS and TVSS measurements for each evaluated $V_{u}$ ) of the granules were assessed every 3-4 days.

\subsection{Analytical methods}

For nitrate, nitrite and orthophosphate analysis, samples were immediately filtrated at $0.45 \mu \mathrm{m}$ followed by $0.2 \mu \mathrm{m}$ using syringe filters (Filtropour S. SARSTEDT, Germany) and analyzed using an Ion Chromatography (930 Compact IC Flex 1 with a Metrosep A Supp 7 -250/4.0 column combined with a 887 Professional UV/VIS detector; Metrohm, Sweden) with $0.1 \mathrm{M} \mathrm{H}_{2} \mathrm{SO}_{4}$ as suppressor and $3.6 \mathrm{mM} \mathrm{Na}_{2} \mathrm{CO}_{3}$ as eluent. The granulation process was evaluated by TVSS and TSS measurements (DS 207, 1985) and SVI determination (APHA, 1995). Ammonia-Nitrogen was analyzed according to DS (1975).

\subsection{Calculations}

Sludge volume index and the specific denitrification rate was calculated according to equations 1 and 2 , respectively.

Sludge volume index $(S V I)=\frac{\text { settled sludge volume } x 1000}{\text { volatile suspended solids }}$

$\left(\frac{m L}{g}\right)$ Eq. 1

Specific denitrification rate $(S D N R)=\frac{Q * \Delta N O_{3}-N}{V * X}$ $\left(\frac{g N O_{3}-N}{g T V S S * d}\right)$ Eq.2 
Where:

\author{
Q: flow rate $(\mathrm{L} / \mathrm{d})$ \\ $\Delta \mathrm{NO}_{3}{ }^{-} \mathrm{N}$ : Change in nitrate concentration $(\mathrm{g} / \mathrm{L})$ in the reactor during $24 \mathrm{~h}$ \\ $\mathrm{V}$ : volume of the reactor $(\mathrm{L})$ \\ $\mathrm{X}$ : biomass concentration in the reactor ( $\mathrm{g}$ TVSS/L)
}

\title{
2.6 Statistical analysis
}

To test for significant differences between specific denitrification rates at different $V_{u}$, a one-way ANOVA analysis followed by a Tukey-Kramer multiple comparison test with $95 \%$ confidence level was applied, considering $p<0.05$ as significant. The statistical analysis was carried out using the R software (R Core Team, 2013).

\subsection{Results}

\subsection{Granulation phase (Phase II)}

The TSS and TVSS values of the denitrifying flocculent sludge from Phase I, used to fill the reactors in Phase II, were 16.9 and $16.5 \mathrm{~g} / \mathrm{L}$, respectively (TVSS/TSS=0.97). At the time of filling, the denitrifying flocculent sludge showed a disaggregated morphology (Fig. 3b). Two days after inoculation, both parameters decreased considerably by $65 \%(5.98 \pm 0.86 \mathrm{~g} / \mathrm{L})$ for TSS and $75 \%$ $(4.50 \pm 0.54 \mathrm{~g} / \mathrm{L})$ for TVSS. From this point onwards and until the end of the granulation phase (day $50)$, the ratio of TVSS/TSS stayed relatively stable at $0.74 \pm 0.1$.

At the start of the granulation phase, the SVI was $42.5 \pm 0.2 \mathrm{~mL} / \mathrm{g}$, decreasing progressively during the course of the experiment, reaching $7.6 \pm 1.4 \mathrm{~mL} / \mathrm{g}$ at day 27 . At this point, a clear formation of granular sludge was seen comprising aggregations of more than $500 \mu \mathrm{m}$ in diameter. At day 28 , the feeding level of nitrate was increased from 250 to $500 \mathrm{mg} / \mathrm{L} \mathrm{NO}_{3}-\mathrm{N}$ in order to evaluate the maximum denitrification capacity of the reactor. Unfortunately, this sudden increment in nitrate resulted in the formation of a considerable amount of bubbles (presumably $\mathrm{N}_{2}$ and $\mathrm{CO}_{2}$ ), affecting the granular settling capacity and thus the evaluated SVI (Fig. 3a). At day 31, the feeding 
concentration of $\mathrm{NO}_{3}-\mathrm{N}$ was reduced to its previous value $\left(250 \mathrm{mg} / \mathrm{L} \mathrm{NO}_{3}-\mathrm{N}\right)$ and on day 42 , a clear granular sludge appeared with granules ranging between 3 and $9 \mathrm{~mm}$ (Fig 3d). From the denitrification rate obtained at day 44 (data not shown), the calculated maximal denitrification capacity was $196.3 \pm 21.6 \mathrm{mg} \mathrm{NO}^{-}{ }^{-} \mathrm{-N} / \mathrm{g}$ VSS/d. At day 50 , the measured SVI was $14.7 \pm 4.3$ and granules were clearly visible and well defined, indicating that they were ready for the performance evaluation (Fig 3e).

During the 50 days granulation phase, the temperature in the reactor was $13.6 \pm 0.9^{\circ} \mathrm{C}$. The $\mathrm{pH}$ value when filling the reactor was $7.9 \pm 0.6$, progressively increasing to $9.4 \pm 0.2$ when the granulation phase was accomplished (day 50).

Figure 3: a) Sludge volume index (SVI) values obtained during the granulation phase (mean \pm SD; $\mathrm{n}=3$ ). b) Morphology of the bacteria/granules during the granulation phase at day $0, \mathrm{c}$ ) day $36, \mathrm{~d}$ ) day 42 , and e) day 51.

\subsection{Performance evaluation (Phase III)}

\subsubsection{Denitrification rates and biomass formation}

During the performance evaluation phase (Fig. 4), the specific denitrification rate increased nonsignificantly from an average of 181.2 to $224.8 \mathrm{mg} \mathrm{NO}_{3}-\mathrm{N} / \mathrm{g}$ TVSS/d at the first two velocities applied ( 0.40 and $0.69 \mathrm{~m} / \mathrm{h})$, corresponding to a nitrate removal efficiency of 96 and $66 \%$, respectively. The highest specific denitrification rate $\left(321.9 \pm 13.1 \mathrm{mg} \mathrm{NO}_{3}{ }^{-}-\mathrm{N} / \mathrm{g}\right.$ TVSS$\left./ \mathrm{d} ; \mathrm{p}<0.05\right)$ was achieved at an upflow velocity of $0.97 \mathrm{~m} / \mathrm{h}$ corresponding to a nitrate removal efficiency of $47 \%$. Increasing upflow velocities beyond this point resulted in a significant decline in the specific denitrification rate down to an average of $122.7 \pm 43.2 \mathrm{mg} \mathrm{NO}_{3}^{-}-\mathrm{N} / \mathrm{g} \mathrm{TVSS} / \mathrm{d}$ at upflow velocities between $1.54-2.11 \mathrm{~m} / \mathrm{h}$, corresponding to nitrate removal efficiencies between 44 and $15 \%$. A considerable mass of bacteria was flushed out of the reactor at a $V_{u}$ of $2.11 \mathrm{~m} / \mathrm{h}$ and the experiment was terminated. 
Bacterial biomass, expressed as TVSS and TSS, increased significantly from 31.6 to $55.2 \mathrm{~g} / \mathrm{L}$ and from 82.0 to $121.9 \mathrm{~g} / \mathrm{L}$, respectively, when $V_{u}$ was raised from 0.40 to $0.69 \mathrm{~m} / \mathrm{h}$ (Table 3). At a $V_{u}$ of $0.97 \mathrm{~m} / \mathrm{h}$ (resulting in the highest specific denitrification rate) the bacterial biomass decreased significantly to $46.3 \mathrm{~g} / \mathrm{L}$ TVSS and $99.2 \mathrm{~g} / \mathrm{L}$ TSS. Further increases in $\mathrm{V}_{\mathrm{u}}$ resulted in further significant reduction in bacterial biomass down to 8 and $11 \mathrm{~g} / \mathrm{L}$ TVSS and TSS, respectively at the highest upflow velocity.

Table 3: Total Volatile Suspended Solids (TVSS) and Total Suspended Solids (TSS) in the upflow anoxic sludge bed (UASB) reactors during the performance phase at different upflow velocities $\left(\mathrm{V}_{\mathrm{u}}\right.$; mean $\pm S D ; n=3)$.

Figure 4: Specific denitrification rates of the reactors ( $\mathrm{mg} \mathrm{NO}_{3}-\mathrm{N} / \mathrm{g}$ TVSS/day; left axis; black dots) (mean $\pm \mathrm{SD} ; \mathrm{n}=3)$ and daily mass load of nitrate $\left(\mathrm{g} \mathrm{NO}_{3}{ }^{-} \mathrm{N} / \mathrm{d}\right)$ applied at the different upflow velocities (right axis; white squares). Black dots not sharing a superscript are statistically different.

\subsubsection{Quality of effluent from the UASB in the performance phase}

In the effluent, orthophosphate and ammonium were always below detection limits while nitrite was detected at all evaluated $\mathrm{V}_{\mathrm{u}}$. Interestingly, the concentration decreased as the upflow velocity increased. Thus, at a $\mathrm{V}_{\mathrm{u}}$ of $0.40 \mathrm{~m} / \mathrm{h}, 52.9 \mathrm{mg} \pm 4.2 \mathrm{NO}_{2}-\mathrm{N} / \mathrm{L}$ was measured in the effluent of the UASB, while at a $V_{u}$ of $2.11 \mathrm{~m} / \mathrm{h}$ only $5.9 \pm 1.4 \mathrm{mg} \mathrm{NO}_{2}-\mathrm{N} / \mathrm{L}$ was found. In comparison, effluent nitrite at the optimal $\mathrm{V}_{\mathrm{u}}(0.97 \mathrm{~m} / \mathrm{h})$ was $35.4 \pm 1.8 \mathrm{mg} \mathrm{NO}_{2}^{-}-\mathrm{N} / \mathrm{L}$ (Fig. 5).

Figure 5: Nitrite concentration ( $\mathrm{mg} \mathrm{NO}_{2}-\mathrm{N} / \mathrm{l}$ ) in the effluent of the UASB at different upflow velocities $(m / h)($ mean $\pm S D ; n=3)$. 
Temperature in the reactor during the performance evaluation was $15.5 \pm 0.5^{\circ} \mathrm{C}$ and $\mathrm{pH}$ was $8.2 \pm$ 0.2. Oxygen saturation measured at the inlet of the UASB was $82 \pm 12.5 \%$ while it was $33 \pm 11.1$ $\%$ in the effluent.

\subsection{Discussion}

\subsection{Granulation phase}

Application of granulation technology in industrial and municipal wastewater treatment has shown promising results. However, one major drawback that has limited its application at industrial scale is the long time (often in the order of 3-8 months) needed for the development of granules (Lettinga et al., 1980; Jin et al., 2012). The current study demonstrated how functional denitrifying granules can be achieved within approximately 1 month by preconditioning rainbow trout organic waste and applying a step-fed batch reactor configuration.

The quality of the preconditioned denitrifying flocculent sludge used for filling the reactors, quantified by the TVSS/TSS ratio, showed good initial conditions for granule formation. The obtained TVSS/TSS ratio of 0.97 demonstrated that a large amount of functional sludge with good settling properties had been formed. After 2 days of operating the UASB reactors, the TVSS/TSS ratio diminished and remained close to $0.76 \pm 0.1$ during the remainder of the experiment. This ratio is within with the range of $0.60-0.85$ reported in previous granulation studies (Lin and Yang, 1991; Lens et al., 1998; Lin and Chen, 1999; Ghangrekar et al., 2005).

The reduction in SVI observed during the granulation phase (Fig. 3) demonstrated an increase in settling capacity of the denitrifying flocculent sludge as it formed into granules. The observed process can be divided in two sub-phases; an adaptation period of approximately 10 days where the denitrifying flocculent sludge conserved its initial inoculum characteristics (SVI of $42-44 \mathrm{~mL} / \mathrm{g}$ ), and a transitional period of 10 days where SVI decreased by approximately $50 \%(20 \mathrm{~mL} / \mathrm{g})$. After the transitional period, SVI remained constant at stable operational conditions within the range previously reported (5 to $20 \mathrm{~mL} / \mathrm{g}$; Ciftci and Ozturk, 1993; Yan and Tay, 1997). 
Different lengths of granulation periods have been reported previously. Wagner et al. (2015), treating domestic wastewater, reported 160 days to achieve mature nitrification and denitrification granules with an average diameter of $0.43 \mathrm{~mm}$ and a SVI of $75.6 \mathrm{~mL} / \mathrm{g}$. Wang et al. (2016) developed anoxic granules (1-2 mm) after approximately 90 days using sodium acetate and sodium nitrate. In comparison, granules of 3 to $9 \mathrm{~mm}$ were already observed at day 27 in the current study. We believe that the use of sodium acetate, the properties of marine water, and the rise of alkalinity due to the denitrification supported the formation of granules (Borzacconi et al., 1999; Yu et al., 2001). Indeed, Val del Rio et al. (2015) found $4.5 \mathrm{~mm}$ granules after 33 days of operating a reactor at an upflow velocity of $0.47 \mathrm{~m} / \mathrm{h}$ and supplying $190 \mathrm{mg} \mathrm{Ca}{ }^{2+} / \mathrm{L}$, demonstrating that increased $\mathrm{Ca}^{2+}$ concentrations can improve granular formation presumably through the precipitation of $\mathrm{CaCO}_{3}$ or $\mathrm{Ca}_{3}\left(\mathrm{PO}_{4}\right)_{2}$. The high $\mathrm{pH}$ values (9.43) observed in the present study probably caused precipitation of $\mathrm{Ca}$ and $\mathrm{P}$ species, thereby promoting granular formation.

\subsection{Denitrifying granular sludge}

The developed granules showed good nitrate removal capacity during the granulation phase (Phase II), reaching a maximal specific denitrification rate of $196.3 \pm 21.6 \mathrm{mg} \mathrm{NO}_{3}{ }^{-} \mathrm{N} / \mathrm{g} \mathrm{VSS} / \mathrm{d}$ similar to what has been reported for wastewater treatment at the given temperature and using acetate as carbon source (Henze et al., 2002).

The highest denitrification rate of $321.9 \pm 13.2 \mathrm{mg} \mathrm{NO}_{3}^{-}-\mathrm{N} / \mathrm{g}$ TVSS/d, registered during performance evaluation (Phase III), matches that achieved in other studies on freshwater granular denitrification reactors applied in wastewater treatment (Klapwijk et al., 1981; Cuervo-Lopez et al., 1999; Jin et al., 2012). However, the rate is higher than the few values previously reported in aquaculture studies using bacterial biomass to remove nitrate. For example, Klas et al. (2006) reported a rate of $45 \mathrm{mg} \mathrm{N} / \mathrm{g}$ TVS/d and Suhr et al. (2014) measured a rate of $294 \mathrm{mg} \mathrm{NO}{ }^{-}-\mathrm{N} / \mathrm{g}$ TVS/d.

When comparing the capacity to remove nitrate per $\mathrm{m}^{3}$ of reactor, aquaculture studies using external carbon sources (with no granular sludge) have previously reported values ranging from 
0.2 to $2.4 \mathrm{~kg} \mathrm{NO}{ }_{3}^{-}-\mathrm{N} / \mathrm{m}^{3}$ reactor/d (Arbiv and van Rijn, 1995; Sauthier et al., 1998; Boley et al., 2000; Müller-Belecke et al., 2013; Suhr et al., 2014). In this experiment, the UASB reactor removed $14.9 \mathrm{~kg} \mathrm{NO}{ }^{-}-\mathrm{N} / \mathrm{m}^{3}$ reactor/d while Klapwijk et al. (1981) achieved removals of at least $12 \mathrm{~kg} \mathrm{NO}{ }^{-}-$ $\mathrm{N} / \mathrm{m}^{3}$ reactor/d using a UASB reactor operated with concentrations around $40 \mathrm{~g} \mathrm{TSS} / \mathrm{L}$. These findings demonstrate that the intense bacterial aggregations achieved in the granules is a key parameter for high removal rates per volume of reactor.

Regarding effluent quality, additional improvements appear necessary since at the optimum upflow velocity, $35.4 \mathrm{mg}$ of $\mathrm{NO}_{2}{ }^{-}-\mathrm{N} / \mathrm{L}$ were discharged from the UASBs. Nitrite discharged from a denitrification system have frequently been reported in aquaculture (Balderston and Sieburth, 1976; Klapwijk et al., 1981; van Rijn et al., 1996; Hamlin et al., 2008; Müller-Belecke et al., 2013; Suhr et al., 2014). It therefore seems like nitrite formation is related to the denitrification process itself rather than to the specific technology applied. Nitrite accumulation can be a consequence of saturation rates and affinities of electron carriers (Almeida et al., 1995), terminal reductases and electron donor oxidation states (Tiedje 1990; van Rijn et al. 1996), and eventually the type of bacteria present in the reactor (Wilderer et al., 1987). In this study, the nitrite concentration discharged from the UASB generally decreased as the up-flow velocities increased (from 52.9 to $5.9 \mathrm{mg} / \mathrm{L} \mathrm{NO}_{2}-\mathrm{N}$; Fig. 5). Probably, two sets of conditions can be attributed to this effect: (1) a true denitrifying bacteria biomass established progressively in the granules (Wilderer et al., 1987) reaching its optimum at the highest evaluated up-flow velocity; and (2) increasing the up-flow velocity improved the diffusion of substrate into the granules. Thus, the substrate (nitrite) penetrated deeper into the granules thereby increasing the contact between bacteria and the substrate (Henze et al., 2008).

All in all, the results showed that if an UASB is to be operated at the optimum up-flow velocity found in this trial $(0.97 \mathrm{~m} / \mathrm{h})$ a further tweaking of the effluent may be needed for optimal end-ofpipe treatment as well as for in-line denitrification, as nitrite can be toxic to fish even at low levels (Timmons et al., 2009). Alternatively, the UASB effluent may be redirected into a concomitant nitrification biofilter whereby nitrite can be oxidized into nitrate, a more "safe" nitrogen compound. 


\subsection{UASB application in marine RAS}

The purpose of evaluating different upflow velocities was to investigate the resulting capacity of the granular marine UASB to treat effluent from saline land based systems. The highest nitrate removal rate obtained in this experiment was achieved at an upflow velocity of $0.97 \mathrm{~m} / \mathrm{h}$, which is in accordance with anaerobic UASB literature values of 0.1 - $10 \mathrm{~m} / \mathrm{h}$ (O'Flaherty et al., 1997; Tchobanoglous et al., 2003; Val del Rio et al., 2015).

An exemplified application of the technology in the industry could be treatment of the effluent from a 1000 ton/y production RAS facility, having a discharge of approximately $1500 \mathrm{~m}^{3} / \mathrm{d}$ containing approximately $66 \mathrm{Kg} \mathrm{NO}_{3}-\mathrm{N} / \mathrm{d}$. Using the results obtained in this study including the optimal upflow velocity, $4.4 \mathrm{Kg}$ granules and a reactor radius of $4.6 \mathrm{~m}$ would be required to remove $100 \%$ of the discharged nitrate. Thus, the UASB reactor would take up relatively little space compared to other typical end-of-pipe treatment technologies (van Rijn et al., 2006). The required radius of this UASB reactor could still however make it impractical for full-scale application in aquaculture. This could be accommodated by increasing the granule weight allowing for a higher upflow velocity in the reactor and reducing the reactor radius. In this manner, UASB could become an alternative way of denitrification in marine aquaculture systems.

\subsection{Conclusions}

- Successful granular formation with high maximal and specific denitrification rates were achieved at day 27 in marine (35 ppt) conditions.

- The highest specific denitrification rate in the UASB reactor $\left(321.9 \pm 13.1 \mathrm{mg} \mathrm{NO}_{3}{ }^{-} \mathrm{N} / \mathrm{g}\right.$ TVSS/d) was achieved at an up-flow velocity of $0.97 \mathrm{~m} / \mathrm{h}$ and a HRT of $1.89 \mathrm{~h}$.

- The UASB granular reactor successfully removed considerable amounts of nitrate per $\mathrm{m}^{3}$ of reactor, thus becoming a promising alternative for end-of-pipe treatment or in-line denitrification in aquaculture. 
- Further studies should focus on increasing upflow velocity, the stability of granules during abrupt changes in operating parameters, and improvement of effluent quality by reducing effluent nitrite concentrations.

\section{Acknowledgments}

This research was funded by The Ministry of Food, Agriculture and Fisheries of Denmark through the GUDP project WASTE-TREAT (GUDP 39190) "Cost effective solutions for End-of-pipe treatment in salt water RAS". The technical skills and invaluable assistance of Brian Møller and Ulla Sproegel (DTU Aqua) are highly appreciated.

\section{References}

Almeida, J., Carrondo, M., 1995. Competition between nitrate and nitrite reduction in denitrification by Pseudomonas fluorescens. Biotechnology and Bioengineering. 46, 476-484.

APHA, 1995. Standard Methods for the Examination of Water and Wastewater, $19^{\text {th }}$ ed. American Public Health Association, Washington DC. 733 pp.

Arbiv, R., van Rijn, J., 1995. Performance of a treatment system for inorganic nitrogen removal in intensive aquaculture system. Aquacultural Engineering. 14, 189-203.

Balderston, W.L., Sieburth, J.M., 1976. Nitrate removal in closed-system aquaculture by columnar denitrification. Applied and Environmental Microbiology. 32, 808-818.

Boley, A., Muller, W.R., Haider, G., 2000. Biodegradable polymers as a solid substrate and biofilm carrier for denitrification in recirculated aquaculture systems. Aquacultural Engineering. 22, 75-85. 
Borzacconi, L. Ottonello, G. Castello, E. Pelaez, H. Gazzola, A. Vinas, M., 1999. Denitrification in a carbon and nitrogen removal system for leachate treatment: performance of an upflow sludge bed (USB) reactor, Water Science Technology. 40, 145-151.

Buvanesh, S., Maneesh, N., Sreekrishnan, T.R., 2013. Start-up and performance of a hybrid anoxic reactor for biological denitrification. Bioresource Technology. 129, 78-84.

Ciftci, T., Ozturk, I., 1993. Anaerobic treatment of the high strength waste from the yeast industry. Water Science Technology. 28, 199-209.

Cuervo-Lopez, F.M., Martinez, F., Gutierrez-Rojas, M., Noyola, R.A., Gomez, J., 1999. Effect of nitrogen loading rate and carbon source on denitrification and sludge settleability in upflow anaerobic sludge bed (UASB) reactors. Water Science Technology. 40, 123-130.

Di Laconi, C., Ramadori, R., Lopez, A., Passino, R., 2005. Hydraulic shear stress calculation in a sequencing batch biofilm reactor with granular biomass. Environmental Science and Technology. 39, 889-894.

DS 207, 1985. Water Analysis - Determination of suspended solids, Danish Standard (DS) 207:1985). 6 pp.

DS 224, 1975. Water Analysis - Determination of Ammonia-Nitrogen, Danish Standard (DS) 224:1975). 8 pp.

Galbova, K., Pagacova, P., Drtil, M., Jonatova, I. 2010. Comparison of anoxic granulation in USB reactors with various inocula. Chemical papers. 64 (2), 132-138. 
Ghangrekar, M.M., Asolekar, S.R., Joshi, S.G., 2005. Characteristics of sludge development under different loading conditions during UASB reactor start-up and granulation. Water research. 39, 1123-1133.

Giesen, A., van Loosdrecht, M., Robertson, S., \& de Buin, B., 2015. Aerobic granular biomass technology: further innovation, system development and design optimisation. Proceedings of the Water Environment Federation. 16, 1897-1917.

Grguric, G., Wetmore, S.S., Fournier, R.W., 2000. Biological denitrification in a closed seawater system. Chemosphere. 40, $549-555$.

Gutierrez-Wing, M.T., Malone, R., Rusch, K., 2012. Evaluation of polyhydroxubutyrate as a carbon source for recirculating aquaculture water denitrification. Aquacultural Engineering. 51, 36 - 43.

Hamlin, H.J., Michaels, J.T., Beaulaton, C.M., Graham, W.F., Dutt, W., Steinbach, P., Losordo, T.M., Schrader, K.K., Main, K.L., 2008. Comparing denitrification rates and carbon sources in commercial scale upflow denitrification filters in aquaculture. Aquacultural Engineering. 38, 79-92.

Henze, M., Harremoës, P., Jansen, J.L.C., Arvin, E., 2002. Wastewater Treatment. Biological and Chemical Process, 3rd ed. Springer. pp. 430.

Henze, M., van Loosdrecht, M., Ekama, G. A., Brjanovic, D. 2008. Biological Wastewater Treatment: principles, modelling and design. IWA Publishing 2008. 511 pp.

Honda, H., Watanaba, Y., Kikuchi, K., Iwata, N., Takeda, S., Uemoto, H., Furata, T., Kiyono, M., 1993. High density rearing of Japanese Flounder, Paralichthys olivaceus with a closed seawater recirculation system equipped with a denitrification unit. Suisanzoshoku. 41, 19-26. 
Jin, X., Wang, F., Liu, G., Yan, N., 2012. A key cultivation technology for denitrifying granular sludge. Process Biochemistry. 47, 1122-1128.

Klapwijk, A., van der Hoeven, J.C.M, Lettinga, G., 1981. Biological denitrification in an upflow sludge bed reactor. Water research. 15, 1-6.

Klas, S., Mozes, N., Lahav, O., 2006. A conceptual, Stoichiometry-based model for single-sludge denitrification in recirculating aquaculture systems. Aquaculture. 259, 328-341.

Lee, K.S., Wu, J.F., Lo, Y.S., Lo, Y.C., Lin, P.J., Chang, J.S., 2004. Anaerobic hydrogen production with an efficient carrier-induced granular sludge bed reactor. Biotechnol. and Bioengineering. 87, 649-657.

Lens, P.N.L., Bosch van Den, M.L., Hulshoff pol, L.W., Lettinga, G., 1998. Effect of staging on volatile fatty acid degradation in sulphidogenic granule reactor. Water Research. 32, 1178-1192.

Lettinga, G., Van Velsen, A., Hobma, S., De Zeeuw, W., Klapwijk, A., 1980. Use of the upflow sludge bed (USB) reactor concept for biological wastewater treatment, especially for anaerobic treatment. Biotechnol. Bioengineering. 22, 699-734.

Lettinga, G., 1995. Anaerobic digestion and wastewater treatment systems. Antoine van leeuwenhoek. 67(1), 3-28.

Lin, K.C., Yang, Z., 1991. Technical review on the UASB process. Int. J. Environ. Stud. 39, 203222. 
Lin, C.-Y., Chen, C.C., 1999. Effect of heavy metals on the methanogenic UASB granules. Water Research. 33, 409-416.

Mirzoyan, N., Tal, Y., Gross, A., 2010. Anaerobic digestion of sludge from intensive recirculating aquaculture systems: Review. Aquaculture. 306, 1-6.

Müller-Belecke, A., Zienert, S., Thürmer, C., Kaufhold, S., Spranger, U., 2013. The "self cleaning inherent gas denitrification-reactor" for nitrate elimination in RAS for pike perch (Sander lucioperca) production. Aquacultural Engineering. 57, 18-23.

O’Flaherty, V., Lens, P.N.L., de Beer, D., Colleran, E., 1997. Effect of feed composition and upflow velocity on aggregate characteristics in anaerobic upflow reactors. Appl. Microbiol. Biotechnology. 47, 102-107.

R Core Team, 2013. R: A Language and Environment for Statistical Computing. RFoundation for Statistical Computing, Vienna, Austria, ISBN 3-900051-07-0http://www.R-project.org/.

Sauthier, N., Grasmick, A., Blancheton, J.P., 1998. Biological denitrification applied to a marine close aquaculture system. Water Research. 32, 1932-1938.

Schmidt, J., Ahring, B., 1996. Granule formation in upflow anaerobic sludge bed (UASB) reactors. Biotechnology and Bioengineering. 49 (3), 229-246.

Suhr, K., Pedersen, L.F., Nielsen, J.L., 2014. End-of-pipe single-sludge denitrification in pilot-scale recirculating aquaculture systems. Aquaculture Engineering. 62, 28-35. 
Suzuki, Y., Maruyama, T., Numate, H., Sato, H., Asakawa, M., 2003. Performance of a closed recirculating system with foam separation, nitrification and denitrification units for intensive culture of eel: towards zero emission. Aquacultural Engineering. 29, 165-182.

Tal, Y., Schreier, H., Sowers, K.R., Stubblefield, J., Place, A., Zohar, Y., 2009. Environmentally sustainable land-based marine aquaculture. Aquaculture. 286, 28-35.

Tchobanoglous, G. Burton, F., Stensel, H. (Eds.), 2003. Wastewater Engineering: Treatment and Reuse. Fourth edition, Metcalf \& Eddy, Inc. McGraw-Hill Companies, Inc., USA. 1819 pp.

Tiedje, J.M., 1990. Ecology of denitrification and dissimilatory nitrate reduction to ammonium. In A.J.B Zehnder (ed), Environmetal microbiology of anaerobes. John Wiley and Sons, N.Y. 179-244 pp.

Timmons, M., Ebeling, J., Piedrahita, R., 2009. Acuicultura en Sistemas de Recirculación. First Edition in Spanish. Editorial CayugaAquaVentures, LLC. Ithaca, NY. 959 pp.

Tsukuda, S., Christianson, L., Kolb, A., Saito, K., Summerfelt, S., 2015. Heterotrophic denitrification of aquaculture effluent using fludized sand biofilters. Aquacultural Engineering. 64, 49-59.

Val del Rio, A., Buys, B., Campos, J.L., Mendez, R., Mosquera-Corral, A., 2015. Optimizing upflow velocity and calcium precipitation in denitrifying granular systems. Process Biochemistry. 50(10), 1656-1661.

van Rijn, J., Fonarev, N., Berkowitz, B., 1995. Anaerobic treatment of intensive fish culture effluents: digestion of fish feed and release of volatile fatty acids. Aquaculture. 133, 9-20. 
van Rijn, J., Tal, Y., Barak, Y., 1996. Influence of volatile fatty acids in nitrite accumulation by a Pseudomonas stutzeri strain isolated from denitrifying fluidized bed reactor. Applied and Environmental Microbiology. 64(7), 2615-2620.

van Rijn, J., Tal, Y., Schreier, H.J., 2006. Denitrification in recirculating systems: theory and application. Aquacultural Engineering. 34, 364-376.

Wagner, J., Guimaraes, L.B., Akaboci, T.R.V., Costa, H.R., 2015. Aerobic granule technology and nitrogen removal for domestic wastewater treatment. Water Science and Technology. 71, 10401046.

Wang, B., Dangcong, P., Zhang, X., Wang, X., 2016. Structure and formation of anoxic granule - A string-bag hypothesis. Front. Environ. Sci. Eng. 10, 311-318.

Wilderer, P. A., Jones, W. L., Dau, U., 1987. Competition in denitrification systems affecting reduction rate and accumulation of nitrite. Water Research. 21, 239-245.

Winkler, M., Bassin, J.P., Kleerebezem, R., van der Lans, R.G.J.M., van Loosdrecht, M.C.M., 2012. Temperature and salt effects on settling velocity in granular sludge technology. Water research. $46,5445-5451$.

Yan, Y.-G., Tay, J.-H., 1997. Characterization of the granulation process during UASB start-up. Water Research. 31,1573-1580.

Yoda, M., Kitagawa, M., Miyaju, Y., 1989. Granular sludge formation in the anaerobic expanded microcarrier bed process. Water Science and Technology. 21, 109-120. 
Yu, Q.H., Tay, J.H., Herbert, H., Fang, P., 1999. Effects of added powdered and granular activated carbons on start-up performance of UASB reactors. Environmental Technology. 20, 1095-1101.

Yu, H. Tay, J. Fang, H.H., 2001. The roles of calcium in sludge granulation during UASB reactor start-up, Water Research. 35, 1052-1060.

\section{Figure captions}

Figure 1: Schematic representation of a granule modified from Giesen et al. (2015).

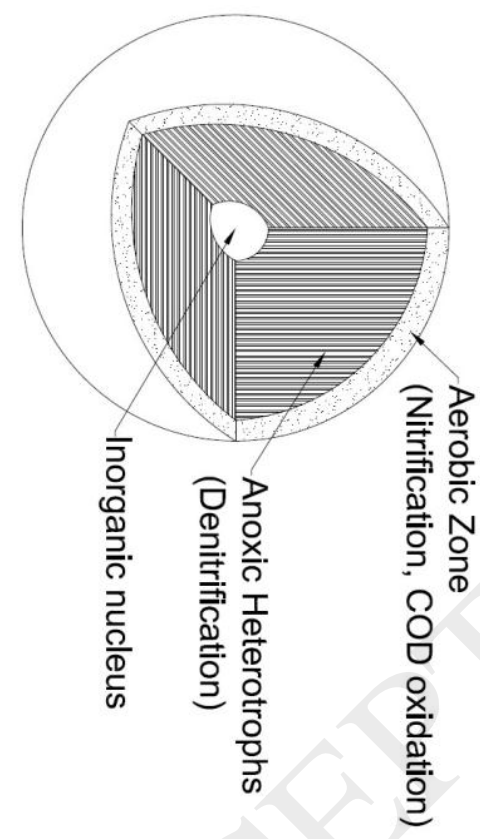

Figure 2: Schematic representation of the UASB set up. 


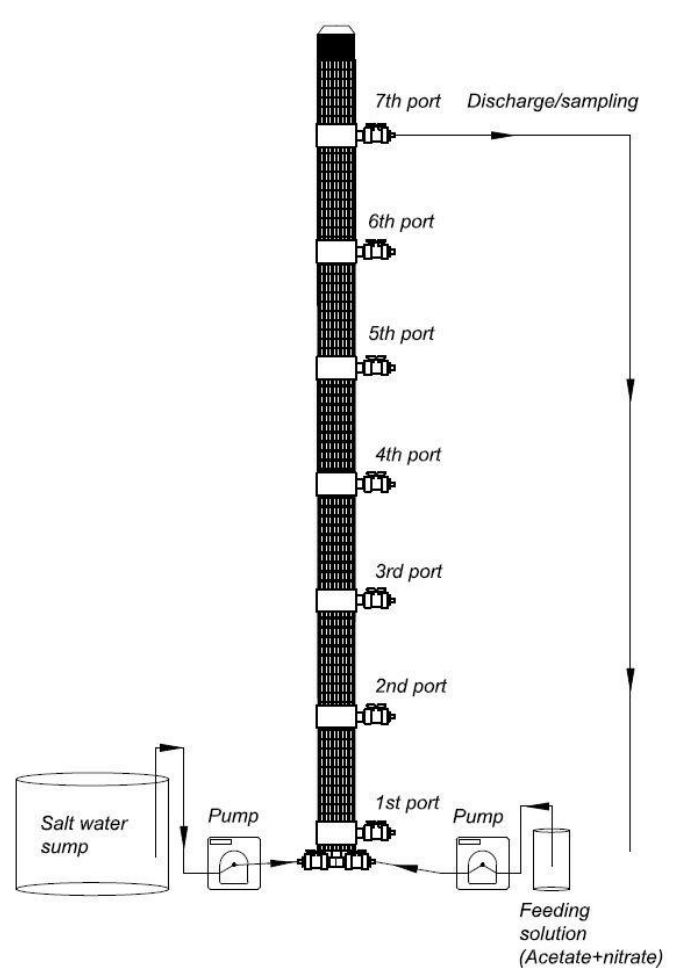

Figure 3: a) Sludge volume index (SVI) values obtained during the granulation phase (mean \pm SD; $n=3)$. b) Morphology of the bacteria/granules during the granulation phase at day $0, c)$ day 36 , d) day 42 , and e) day 51.

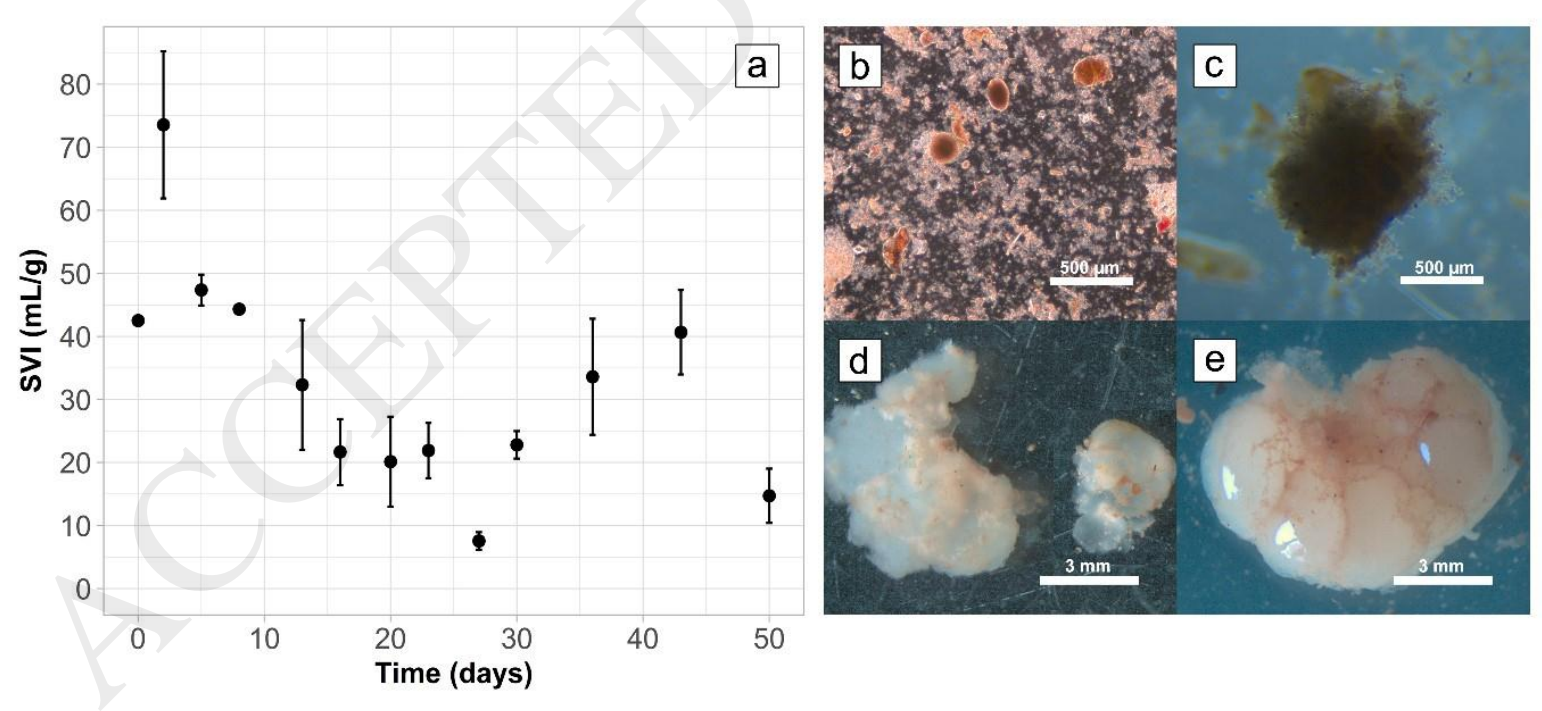


Figure 4: Specific denitrification rates of the reactors ( $\mathrm{mg} \mathrm{NO}_{3}{ }^{-} \mathrm{N} / \mathrm{g}$ TVSS/day; left axis; black dots) (mean $\pm \mathrm{SD} ; \mathrm{n}=3)$ and daily mass load of nitrate $\left(\mathrm{g} \mathrm{NO}_{3}{ }^{-}-\mathrm{N} / \mathrm{d}\right)$ applied at the different upflow velocities (right axis; white squares). Black dots not sharing a superscript are statistically different.

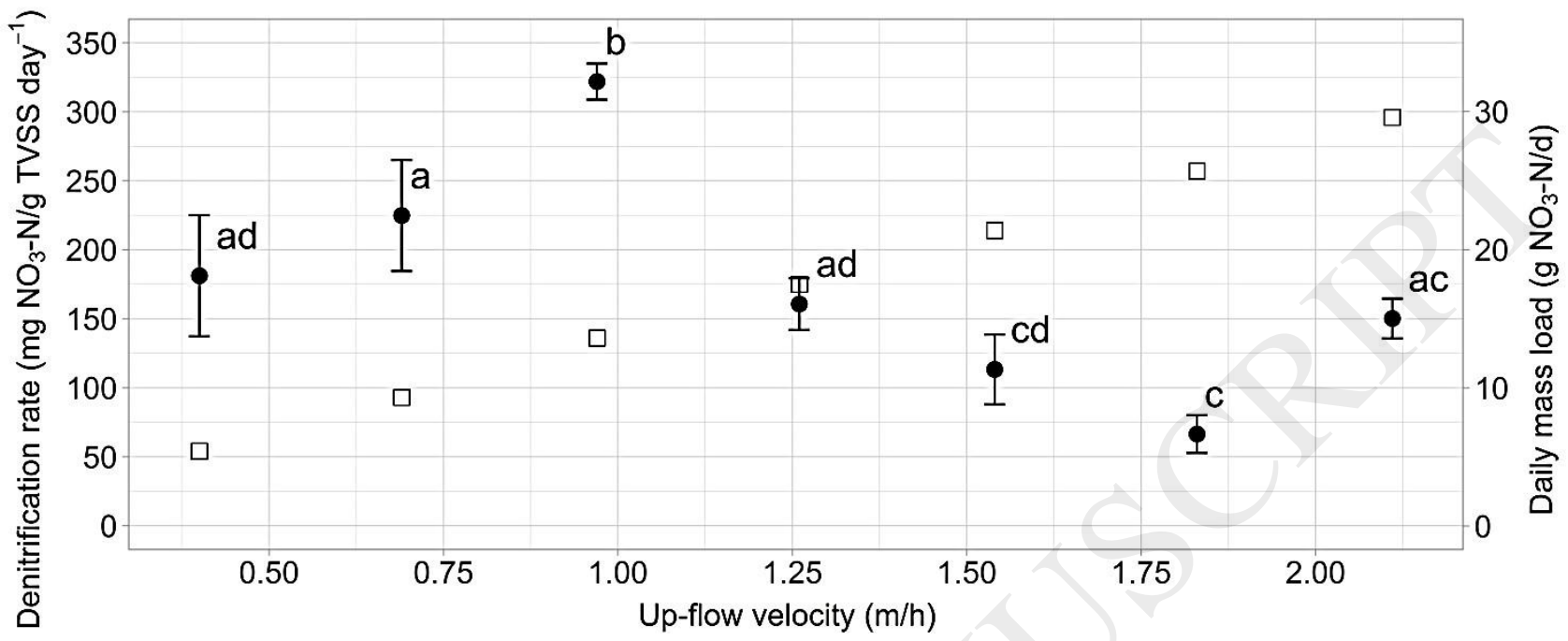

Figure 5: Nitrite concentration ( $\mathrm{mg} \mathrm{NO}_{2}-\mathrm{N} / \mathrm{L}$ ) in the effluent of the UASB at different upflow velocities $(m / h)($ mean $\pm S D ; n=3)$.

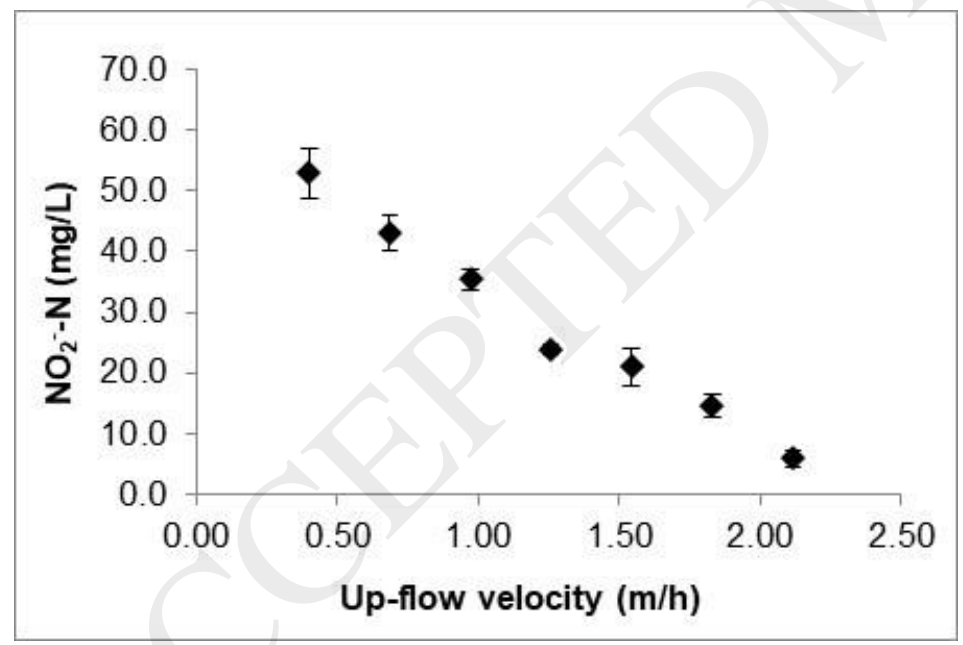

Table 1: Overview of the experimental time schedule and applied operational carbon and nitrate concentrations in the UASB reactors $(n=3)$.

\begin{tabular}{|l|l|l|l|l|}
\hline & Experimental stage & Operational mode & Upflow velocity & $\mathrm{NO}_{3}{ }^{-}-\mathrm{N}$ \\
\hline
\end{tabular}




\begin{tabular}{|c|c|c|c|c|}
\hline Week & & & $\mathrm{V}_{\mathrm{u}}(\mathrm{m} / \mathrm{h})$ & $(\mathrm{mg} / \mathrm{L})$ \\
\hline 1 & Inoculum & & & \\
\hline 2 & $\begin{array}{c}\text { preparation } \\
\text { (Phase I) }\end{array}$ & Step-fed batch & - & $250^{a}$ \\
\hline 3 & \multirow{6}{*}{$\begin{array}{c}\text { Granulation phase } \\
\text { (Phase II) }\end{array}$} & \multirow{6}{*}{ Step-fed batch } & 0.40 & $250^{a}$ \\
\hline 4 & & & 0.40 & $250^{a}$ \\
\hline 5 & & & 0.40 & $250^{a}$ \\
\hline 6 & & & 0.40 & $250^{a}$ \\
\hline 7 & & & 0.40 & $500-250^{a}$ \\
\hline 8 & & & 0.40 & $250^{\mathrm{a}}$ \\
\hline 9 & \multirow{7}{*}{$\begin{array}{c}\text { Performance phase } \\
\text { (Phase III) }\end{array}$} & \multirow{7}{*}{ Flow-through } & 0.40 & $100^{b}$ \\
\hline 10 & & & 0.68 & $100^{b}$ \\
\hline 11 & & & 0.97 & $100^{b}$ \\
\hline 12 & & & 1.26 & $100^{b}$ \\
\hline 13 & & & 1.54 & $100^{b}$ \\
\hline 14 & & & 1.83 & $100^{b}$ \\
\hline 15 & & & 2.11 & $100^{b}$ \\
\hline
\end{tabular}

a Initial concentration at the beginning of each cycle under a step-fed batch configuration of 1 cycle/day. ${ }^{b}$ Concentration at which the UASB reactor operated under a flow-through configuration.

Table 2: Up-flow velocities $\left(\mathrm{V}_{\mathrm{u}}\right)$, hydraulic retention time $(\mathrm{HRT})$, flow and daily mass of feeding solution delivered to each of the triplicate UASB reactors in the performance phase (Phase III).

\begin{tabular}{|c|l|c|c|c|c|}
\hline Week & $\mathrm{V}_{\mathrm{u}}$ & HRT & Flow & Nutrient added & Organic carbon \\
& $(\mathrm{m} / \mathrm{h})$ & $(\mathrm{h})$ & $(\mathrm{L} / \mathrm{d})$ & $\left(\mathrm{g} \mathrm{NO}_{3}-\mathrm{N} / \mathrm{d}\right)$ & added \\
& & & & & $(\mathrm{g}$ acetate $/ \mathrm{d})$ \\
\hline
\end{tabular}




\begin{tabular}{|c|c|c|c|c|c|}
\hline 1 & 0.40 & 4.76 & 54.1 & 5 & 34.8 \\
\hline 2 & 0.69 & 2.77 & 93.0 & 9 & 59.7 \\
\hline 3 & 0.97 & 1.89 & 136.2 & 14 & 87.5 \\
\hline 4 & 1.26 & 1.47 & 175.1 & 18 & 112.4 \\
\hline 5 & 1.54 & 1.21 & 214.0 & 21 & 137.4 \\
\hline 6 & 1.83 & 1.00 & 257.2 & 26 & 165.1 \\
\hline 7 & 2.11 & 0.87 & 196.1 & 30 & 190.1 \\
\hline
\end{tabular}

Table 3. Total Volatile Suspended Solids (TVSS) and Total Suspended Solids (TSS) in the upflow anoxic sludge bed (UASB) reactors during the performance phase at different upflow velocities $\left(\mathrm{V}_{\mathrm{u}}\right.$; mean $\pm S D ; n=3)$.

\begin{tabular}{|c|c|c|}
\hline $\begin{array}{c}\mathrm{V}_{\mathrm{u}} \\
(\mathrm{m} / \mathrm{h})\end{array}$ & $\begin{array}{c}\text { TVSS } \\
(\mathrm{g} / \mathrm{L})\end{array}$ & $\begin{array}{c}\text { TSS } \\
(\mathrm{g} / \mathrm{L})\end{array}$ \\
\hline 0.40 & $31.6 \pm 1.3$ & $82.0 \pm 4.5$ \\
\hline 0.69 & $55.2 \pm 1.3$ & $121.9 \pm 2.3$ \\
\hline 0.97 & $46.3 \pm 2.4$ & $99.2 \pm 5.6$ \\
\hline 1.26 & $29.3 \pm 1.7$ & $56.2 \pm 4.0$ \\
\hline 1.54 & $30.9 \pm 4.3$ & $51.1 \pm 7.9$ \\
\hline
\end{tabular}




\begin{tabular}{|l|c|c|}
\hline 1.83 & $24.8 \pm 7.45$ & $35.2 \pm 12.0$ \\
\hline 2.11 & $7.5 \pm 1.1$ & $11.0 \pm 0.5$ \\
\hline
\end{tabular}

